\title{
Predicaments in Business Ventures Encountered by Women Entrepreneurs in Malaysia
}

\author{
Submitted 03/04/21, $1^{\text {st }}$ revision 28/04/21, $2^{\text {nd }}$ revision 15/05/21, accepted 05/06/21
}

\begin{abstract}
Arasu Raman ${ }^{1}$
Abstract:

Purpose: This paper summarizes the effect of empirical debate on the topic of female entrepreneurship in Malaysia. The study was based on a highly systematic method of hypothesis, the researcher's systematization and statistical generalizations of experimental developments provided the foundation for the formulation of the hypothesis, and observational experiments were aimed at evaluating this hypothesis and describing the causal associations between the variables.

Design/Methodology/Approach: A survey of 100 respondents is used to collect data and the findings of an analytical review of survey data enabled the identification of three major groups of factors that stymie the growth of female entrepreneurship in Malaysia, namely lack of enforcement. The impact of both influences on the growth of value-added from female entrepreneurs' businesses was investigated in the paper using statistical analysis.

Findings: The findings of this study corroborate those women entrepreneurs fail due to gender discrimination, gender-biased stereotypes, family obligations, a lack of funds, and a perception of male dominance, all of which are highly influential factors in Malaysia.

Practical implication: The researcher proposes that federal and state government agencies and municipal governments must ensure financial assistance for female entrepreneurs, paternity policies and incentives for mothers, anti-discrimination enforcement, and educational efforts centered on female entrepreneurship empowerment. This study can overcome women's reluctance to engage in entrepreneurship not only in Malaysia, but also in other developing countries.

Originality/Value: Although changing these established ideas might take time, it is vital for long-term change. The key obligation of the government and society will be to acknowledge the magnitude of the obstacles faced by female entrepreneurs, which may already be on the government's agenda.
\end{abstract}

Keywords: Female entrepreneurs, entrepreneurial enforcement, business equality.

JEL Classification: $\mathrm{O} 2, \mathrm{O}, \mathrm{M} 3$

Paper Type: Research Paper.

Acknowledgement: The author expresses his sincere thanks to the 100 participants from 12 companies for the data collection process of the study.

\footnotetext{
${ }^{1}$ Senior Lecturer at Faculty of Business, Communications and Law, INTI International University, Malaysia.Email: arasu.raman@newinti.edu.my
} 


\section{Introduction}

Female entrepreneurs are expected to increase in the future, according to research, but the current percentage of female entrepreneurs is about $40 \%$ globally, with a male-to-female entrepreneur ratio as high as 5:1 (Radicioni, 2017). As published by SMEBIZ (2018), just 20\% of Malaysian women are involved in entrepreneurship, even though entrepreneurship is critical in developing countries such as Malaysia. Furthermore, male entrepreneurs control 50\% of the businesses in Malaysia (Zhu and Kuriyama, 2016).

Women entrepreneurs are forced to suffer and experience more pressures than male entrepreneurs after they have opted to participate in entrepreneurship in order to respond to the fluctuating circumstances in terms of gender equity in both culture and the workplace (Hossain, Jahangir, and Al-Ahad, 2018). Idris and Tan (2017) confirms that some financial institutions are unable to lend to female entrepreneurs because they believe women are less trustworthy and efficient than men. Even though entrepreneurs do contribute to the local economy, it is unfortunate that some backward inequality still exists and is worsening the gender-biased condition.

Figure 1. Pay Inequality Between Men and Women in Malaysia

\section{INCOME}

On average, in Malaysia, for every $\$ 1$ you earn, a man earns $\$ 1.54$

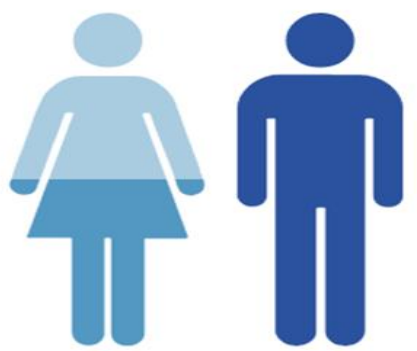

Source: Lee, 2016

Starting in 2012, nearly 126 million people in 67 countries began a new enterprise, and 98 million women are expanding already developed companies. However, the proportion of women entrepreneurs varies from $1 \%$ to $40 \%$ in different countries around the world based on economic growth, so the effect of female entrepreneurship on economic development is especially important for developing countries, particularly Malaysia. Figure 1 and Figure 2 depicts this inequality. 
Figure 2. Gender Pay Gap Between Men and Women in Malaysia

In Malaysia, the average annual salary for a woman is $\$ 20,105.47$ and average annual salary for a man is $\$ 30,828.22$.

\section{WOMEN}

\section{MEN}

Source: Lee, 2016.

Although the Malaysian government's goal of rapid growth in the number of female entrepreneurs is a top priority, the long-term viability and longevity of newly developed business projects are also critical (Osman, 2018). Although numerous studies on women entrepreneurs in Malaysia have been conducted, there has been no clear study conducted by scholars that could include frameworks or explanations for how they were able to continue their business projects and become profitable (Lee, 2016). Such studies that clearly describe the driving factors or circumstances that contributed to their success as women entrepreneurs could provide useful learning opportunities for aspiring businesswomen (Suaibah et al., 2012).

\subsection{Proposed Study}

To foster an awareness of the issues and constraints confronting female entrepreneurs, this research is attempting to conduct comprehensive analysis that is statistically significant and could provide a response to the real question: What are the primary constraints and issues confronting female entrepreneurs in Malaysia? Apart from that, the aim of this study is to ascertain the constraints faced by Malaysian female entrepreneurs, as well as the motivating factors that influence their entrepreneurial decisions and subsequent advancements (Osman and Salleh, 2007). Additionally, this analysis report would highlight any proposed or implemented compliance measures against woman entrepreneurs by Malaysian authorities.

Aside from that, though extensive research on effective female entrepreneurs have been conducted by various authors in Western environments, these factors may vary in the Malaysian context (Idris and Tan, 2017). These disparities in the cultural context, market environment, level of education, policies, and modes of activity of Malaysian women may influence the success or failure of indigenous businesses (Hossain, Jahangir, and Al-Ahad, 2018). Thus, a quantitative analysis is needed to get a better understanding of the climate, key performance drivers, and other influencing factors. 
The importance of using a quantitative analysis method is that it places a premium on explaining and comprehending dynamic phenomena (Idris and Tan, 2017). It will promote the investigation of the relationships and trends between causes or patterns in which women's business practices occur in this research. It is focused on gaining a holistic view of the topic of study, i.e., what aspects led to the success of woman entrepreneurs and how they achieved it (Watkins, 2007). This will aid in developing a thorough understanding of the factors affecting the progress of women entrepreneurs in Malaysia (Osman, 2018).

Therefore, the specific aim of this research study is to identify potential enforcements for women entrepreneurs carried out by Malaysian authorities. This study seeks to address the following questions: Can a shortage of future compliance impact women's inability to participate in entrepreneurship? The assumption is that there is a strong association between a shortage of possible enforcements and women's reluctance to participate in entrepreneurship.

\section{Literature Review}

\subsection{Related Studies on Entrepreneurs}

Entrepreneurs, a community of businesspeople known as a driver for economic development and growth, will help a country's economic development and growth. They are regarded as a community of individuals who are constantly determined to put fresh thoughts into action and can take chances. As stated by Anwar and Rashid (2012), women entrepreneurs are individuals who use their skills and expertise to build or grow prospects for new companies, whether this be casually in a home situation without formally enlisting their company or explicitly by business enrolment, hiring office space, and so on.

Female founders are also in charge of the day-to-day operations of their businesses, have been in practice and have specific expertise for more than a year, and regularly engage in working with their organizations. This has specifically shown what entrepreneurship practices are carried out by female entrepreneurs. Furthermore, a female businessperson needs' accomplishment motivation/inspiration, 'which is the must and urge to achieve any goal. An individual with strong enterprising inspiration would not want to have a fixed salaried job, even though he or she is given a good salary.

Female entrepreneurs in Malaysia are more likely to be involved in businesses that do not pose too many risks (Idris, 2005). Nonetheless, the Malaysian government has adopted economic operations as one of the primary approaches to reducing poverty within women's society. Malaysian women have been involved in the commercial area for a long time following the customs. The business sector appears to have created another platform and opportunity for the women's community to earn an additional income outside of the home, but their share remains insignificant when 
compared to male entrepreneurs. The pursuit of the writing revealed that there is still a shortage of research information concerning women entrepreneurs in Malaysia. There has not been much research or reliable information concerning the contributions of female entrepreneurs in the Malaysian industry. What is known is that the total number of women in working organizations has steadily climbed year after year.

The past two decades has been portrayed as the time when more Malaysian women entered the business world. However, except from the research of Yunus and Gadar (2009), Chong and Teoh (2008), and Osman and Salleh (2007), no other research on female entrepreneurs in Malaysia has been covered in this context. With the local government still zealous in its desire to increase and empower the Malaysian women's community in terms of entrepreneurship, more research, and data relevant to female entrepreneurs in Malaysia, such as what support female entrepreneurs require, what issues they face, and what factors contribute to their success, should be investigated. There should be a reputable source that studies Malaysian successful entrepreneurs. As a result, there is a strong desire to learn more about how female entrepreneurs may be prosperous in Malaysia. Once the successful and effective entrepreneurial processes among female entrepreneurs have been established, analyzed, and explored into a good model of female entrepreneurial growth, it may be used as a reference for other prospective and aspiring female micro entrepreneurs.

As a result, the primary goal of this explanatory study is to create an extended knowledge that useful to the authorities to improve the contribution of female entrepreneurs to the development of Malaysia's socioeconomics, as well as to provide more in-depth and comprehensive quantitative data from Malaysian successful female entrepreneurs.

\subsection{Malaysia's Entrepreneurialism}

In general, male entrepreneurs in Malaysia manage and operate a significant portion of private ventures in Malaysia. However, the good news is that an increasing number of Malaysian women have recently begun to participate in the development of new industries as well as the establishment of their own companies. The increasing rate of Malaysian women starting their own businesses in industries such as health care, restaurants, consultancy, ICT (Information Communication Technology), jewelry, souvenirs, cosmetics, halal food manufacturing, apparel, textiles, and clothes could show and prove this pattern.

In Malaysia, most female entrepreneurs are involved in the wholesale, supermarket, and hawker industries. Many female entrepreneurs are entering the F \& B (Food and Beverage) markets, as well as selling self-designed clothing and retailing (Suaibah et al., 2005). As the reasons described by Fatimah (1975), Malaysian women to work in these sectors are the lower possible danger, the lack of complicated skills, the lack of high resources, and the lack of qualified labor to operate the businesses. 
According to the literature review that is applicable to Malaysian female entrepreneurs, Malaysia should undertake additional relevant studies on this type of issue. Various themes have emerged because of these limited inquiries. Osman and Salleh (2007), in their research on Malaysian female entrepreneurs, when all is said and finished, female entrepreneurs have a higher monetary propensity motivation for starting a company. Many Malaysian women choose to invest in a business enterprise mostly to improve and financially support their families' everyday lives.

The types of business projects are mostly clear business exercises that are housebased ventures as well as miniaturized scale-level business that involve basic critical creativity. These organizations, which involve low-innovation organizations as well, commonly require manual labor, which is widely practiced in Malaysia. Administrative assistance is provided by various Malaysian government agencies, including the Department of Agriculture (DOA), the Department of Community Development (KEMAS), the Ministry of Regional and Rural Development, the Ministry of Women, Family, and Community Development, and the State Economic Development Corporation (SEDC) (Osman, 2018).

The lack of effective Malaysian authorities' enforcements plays an important role in the respondents' unwillingness to participate in entrepreneurship, and it was specifically stated that potential enforcement would help in a significant improvement in the numbers of Malaysian women entrepreneurs participating in the entrepreneurs. Like the research of Mutalib et al. (2015), future enforcements are relevant when it comes to acceptance in the trajectory of raising the size of Malaysian female entrepreneurs. It is also supported by (Ariffin, Baqutayan, and Mahdzir, 2017) in their analysis. The impression that the Malaysian government's lax compliance is a barrier to more advancements in entrepreneurship, encouraging Malaysian women entrepreneurs to start-up companies.

\section{Methodology}

This is a quantitative study. Thus, purposive sampling method is used to choose 100 respondents in Malaysia. The places on which adjacent working offices or corporate headquarters have been concentrated to maintain continuity. Due to the research's focus on quantitative approaches. For data collection purposes, the researcher's target respondents' companies fall under the category of Small and Medium Enterprises. That is, 100 female managers were selected by a convenient sampling process. Face-to-face interviews are used to gather responses.

The study's general population is managerial level women in Malaysia. The questionnaires were sent to the 100 women (companies) selected for this study who hold managerial positions in Malaysia. To reiterate, the overarching goal of this study is to ascertain their degree of curiosity and concern about why they are not pursuing self-enterprising business projects. The researcher used an online questionnaire as the research instrument. In fact, during the COVID-19 lockdown 
period, a researchable questionnaire was used to collect primary data from respondents in a short period of time. The online questionnaire takes respondents' responses within days. IBM SPSS Statistics has been used to analyze the data of the study.

\section{Results and Implication}

18 of the 19 items are valid and reliable in this study since they all have a value greater than 0.5. Lack of Potential Enforcement has a Cronbach's Alpha of 0.847. Additionally, the Cronbach's Alpha for Women's Unwillingness to Participate in Entrepreneurship is 0.806. The ANOVA test, Pearson's Correlation Coefficient, and Regression Analysis were used to analyze the association and variance between the variables in this study. The following table summarizes the findings. Based on Regression Model, the value of $\mathrm{R}$ is 0.829 and it indicates the value of correlation is high.

Moreover, the value of obtained $\mathrm{R}$ Square is 0.687 indicating that $68.7 \%$ of Unwillingness of Women towards Participation in Entrepreneurship in Malaysia explained by the Lack of Potential Enforcement. Then according to Pearson Correlation, there is a strongly positive association between lack of possible enforcement (independent variable) and women's inability to participate in entrepreneurship (dependent variable). The absence of proper enforcement has a 0.696 association with women's aversion to entrepreneurship. As a result, when the likelihood of enforcement is high, women's reluctance to participate in entrepreneurship is often high (Table 1).

Table 1. Model Summary of Lack of Potential Enforcement and Women's Entrepreneurial Inability

\begin{tabular}{|c|c|c|c|c|c|c|}
\hline Model & $\mathrm{R}$ & R Square & $\begin{array}{c}\text { Adjusted R } \\
\text { Square }\end{array}$ & $\begin{array}{c}\text { Std. Error of } \\
\text { the Estimate }\end{array}$ & $\begin{array}{c}\text { Sig. F } \\
\text { Change }\end{array}$ & $\begin{array}{c}\text { Durbin- } \\
\text { Watson }\end{array}$ \\
\hline 1 & $.829^{\mathrm{a}}$ & .687 & .677 & .33089 & .000 & 1.884 \\
\hline
\end{tabular}

Note: a. Predictor: (Constant), Lack of Potential Enforcement

b. Dependent Variable: Women's Entrepreneurial Inability

Source: Own study.

Lack of enforcement is statistically significant with a p-value of 0.031 as well as a tvalue of 2.183, which means that lack of potential enforcement has approximately $22 \%$ strength. Each point improvement of lack of potential enforcement intensifies the reluctance of women towards involvement in entrepreneurship by 0.201 as the standardized coefficients value Beta for lack of potential enforcement is +0.201 . Therefore, the lack of potential enforcement has a significant relationship with the inability or unwillingness of women towards participation in entrepreneurship in Malaysia (Table 2). 
Table 2. Coefficients of Lack of Potential Enforcement and Women's Entrepreneurial Inability

\begin{tabular}{|l|c|c|c|c|c|}
\hline \multirow{2}{*}{\multicolumn{1}{|c|}{ Model }} & \multicolumn{2}{|c|}{$\begin{array}{c}\text { Unstandardized } \\
\text { Coefficients }\end{array}$} & $\begin{array}{c}\text { Standardized } \\
\text { Coefficients }\end{array}$ & \multirow{2}{*}{} & \multirow{2}{*}{ Sig. } \\
\cline { 2 - 4 } & $\mathrm{B}$ & Std. Error & Beta & $\mathrm{t}$ & .001 \\
\hline (Constant) & .828 & .253 & & 3.270 & .031 \\
\hline Lack of Enforcement & .193 & .088 & .201 & 2.183 & .031 \\
\hline
\end{tabular}

a. Dependent Variable: Women's Entrepreneurial Inability

Source: Own study.

The equation of the variables is summarized as follows:

$\mathrm{Y}=0.828+0.193 \mathrm{E}$

Where, Y= Unwillingness of Women towards Participation in Entrepreneurship.

$\mathrm{E}=$ Lack of Potential Enforcement.

Linear regression analysis concludes that lack of potential enforcement of planned programs at all levels of the government and private agencies has a significant beneficial effect on women's inability to participate in entrepreneurship. This variable is inclusive of financial assistance for female entrepreneurs, paternity policies and incentives for mothers, anti-discrimination enforcement, and educational efforts centered on female entrepreneurship empowerment, among others. As a result, there is a strong positive correlation between a shortage of potential enforcement and women's reluctance to engage in entrepreneurship.

\section{Conclusion}

This research established a positive significant association between a lack of potential enforcement and women's reluctance to participate in entrepreneurship. In line with the result of the study, Ariffin, Baqutayan, and Mahdzir (2017), found the more government enforcements, the more female working adults participate in entrepreneurship in Malaysia, so effective policies promoting female entrepreneurship must be inclusive to assist female entrepreneurs in overcoming business constraints. With these, more Malaysian women would eventually be able to establish their own businesses.

According to Lim and Lee (2017), there is a substantial connection between future compliance and the involvement of Malaysian women in entrepreneurship, as most of the female entrepreneurs' report that receiving financial assistance from the Malaysian government is one of the primary factors motivating them to launch their own business projects. Thus, it is critical to introduce proper enforcement to increase Malaysian women's entrepreneurial involvement. Apart from that, Malaysia's antidiscrimination regulations, as well as maternal and paternity policies and incentives, 
are also insufficient, given the clear correlation between promoting compliance and female entrepreneurship in Malaysia (Zhu and Kuriyama, 2016).

Female entrepreneurs approach the business environment in Malaysia for a variety of reasons, including the need to be financially stable, the desire to increase financial opportunities, personal success, and the desire to seek additional obstacles and experiences in life. The findings of this study corroborate the study's conclusion that women entrepreneurs fail due to gender discrimination, gender-biased stereotypes, family obligations, a lack of funds, and a perception of male dominance, all of which are highly influential factors in Malaysia. As a result, their growth is slow. But, if these factors are addressed effectively, the growth of women entrepreneurs will accelerate. A dynamic web of conventions, ideologies, ideals, behaviors, and stereotypes rooted in history and past memory weaves its way across several tiers of every culture. The patriarchal nature of orthodox culture persists, and the wealthy continue to move land along patriarchal lines. Although the effort to alter these entrenched mindsets can be gradual, it is critical for long-term reform. The government and society's primary responsibility will be to recognize the extent of the challenges confronted by women entrepreneurs, which could already be on the government's agenda.

\section{References}

Anwar, M., Rashid, D. 2012. Female Entrepreneurs - A Review of the Literature and Proposed Conceptual Framework. [online] Umt.edu.pk. Retrieved from: https://www.umt.edu.pk/icobm2012/pdf/2C-78P.pdf.

Ariffin, A., Baqutayan, S., Mahdzir, A. 2017. Enhancing Women Entrepreneurship Development Framework: Policy \& Institution Gap and Challenges in the Case of Malaysia. [online] Jostip.org. Retrieved from: http://www.jostip.org/index.php/jostip/article/view/57.

Chong, S., Teoh, M. 2008. Improving Women Entrepreneurs in Small and Medium Enterprises in Malaysia: Policy Recommendations. [online] Pdfs.semanticscholar.org. Retrieved from: https://pdfs.semanticscholar.org/f8a1/79b2285f14bddecc5c1219d3dbfc80240659.pdf.

Fatimah, D. 1975. Penyertaan wanita Bumiputra dalam bidang perniagaan dan perusahaan di Kuala Lumpur. [online] Google Books. Retrieved from: https://books.google.com.my/books/about/Penyertaan_wanita_Bumiputra_dalam_bidang .html?id=q2iQAQAACAAJ\&redir_esc=y.

Hossain, J., Jahangir, N., Al-Ahad, M. 2018. A Study on Female Entrepreneurs. [online] Armgpublishing.sumdu.edu.ua. Retrieved from: http://armgpublishing.sumdu.edu.ua/wp-content/uploads/2016/12/files/bel/volume-2issue-3/6.pdf.

Idris, N. 2005. Keupayaan Mengeksport Produk Makanan Halal Di Kalangan Pengusaha PKS Di Malaysia. [online] Ukm.my. Retrieved from: http://www.ukm.my/hairun/kertas\%20kerja\%20iCEPs/Keupayaan\%20Mengeksport\%20 Produk\%20Makanan\%20Halal.pdf.

Idris, N., Tan, J. 2017. Review of Literature on Women Entrepreneurs. [online] Gbse.com.my. Retrieved from: http://gbse.com.my/v1no3jan17/Paper-40-.pdf. 
Lee, S. 2016. Building Gender Equality in the Workforce. [online] TopNotch. Retrieved from: https://topnotchgroup.com.my/building-gender-equality-in-the-workforce/.

Lim, O., Lee, K. 2017. Innovation Management: A Study of Woman Entrepreneurs in Klang Valley. [online] Research Gate. Retrieved from: https://www.researchgate.net/publication/312147174_Innovation_Management_A_Stud y_of_Woman_Entrepreneurs_in_Klang_Valley.

Mutalib, R., Arshad, R., Ismail, N., Ahmad, Z. 2015. Women and Entrepreneurship: An Overview of Women Entrepreneurship Programs in Malaysia. [online] Repo.uum.edu.my. Retrieved from: http://repo.uum.edu.my/15205/1/Ar.pdf.

Osman, C. 2018. An Exploratory Study of Malaysian Women Entrepreneurs: What Drives Them into Business. [online] Academia. Retrieved from: https://www.academia.edu/38107641/An_Exploratory_Study_of_Malaysian_Women_E ntrepreneurs_What_Drives_Them_into_Business.

Osman, M., Salleh, Z. 2007. Goal Orientations and Typology of Women Entrepreneurs. [online] Jurnalkemanusiaan.utm.my. Retrieved from: https://jurnalkemanusiaan.utm.my/index.php/kemanusiaan/article/view/174.

SMEBIZ. 2018. Giving female entrepreneurs a boost. [online] The Star Online. Retrieved from: https://www.thestar.com.my/business/smebiz/2018/05/07/giving-femaleentrepreneurs-a-boost.

Suaibah, A.B., Azlah, M.A., Hishamuddin, M.S., Rozeyta, O., Syaharizatul, N.M., Rosilla, R. 2012. Development of Women Entrepreneurs: The Case of Malaysia. [online] Semantic Scholar. Retrieved from: https://pdfs.semanticscholar.org/7230/a96c7a1846d85b2d00f2b37519cd88d6c3c9.pdf.

Radicioni, B. 2017. Women's Entrepreneurial Activity Up 10 Percent, Closing the Gender Gap By 5 Percent Since 2014. [online] Babson.edu. Retrieved from: https://www.babson.edu/about/news-events/babson-announcements/globalentrepreneurship-monitor-womens-report/.

Watkins, D. 2007. Koli National Park: Incubation for Regional Economic Development and Environmental Protection Through Multi-Level Entrepreneurship (Interactive Paper). [online] Digital Knowledge at Babson. Retrieved from: https://digitalknowledge.babson.edu/fer/vol27/iss23/4/.

Yunus, N., Gadar, K. 2009. The Influence of Personality and Socio-Economic Factors on Female Entrepreneurship Motivations in Malaysia. [online] Pdfs.semanticscholar.org. Retrieved from: https://pdfs.semanticscholar.org/3c48/5e0356bd6629789e934c2a5af804ddec559d.pdf.

Zhu, H., Kuriyama, C. 2016. Gender Equality \& Trade Policy. [online] 1pdf.net. Retrieved from: https://1pdf.net/gender-equality-trade-policy_5870decfe12e89027700e2ee. 